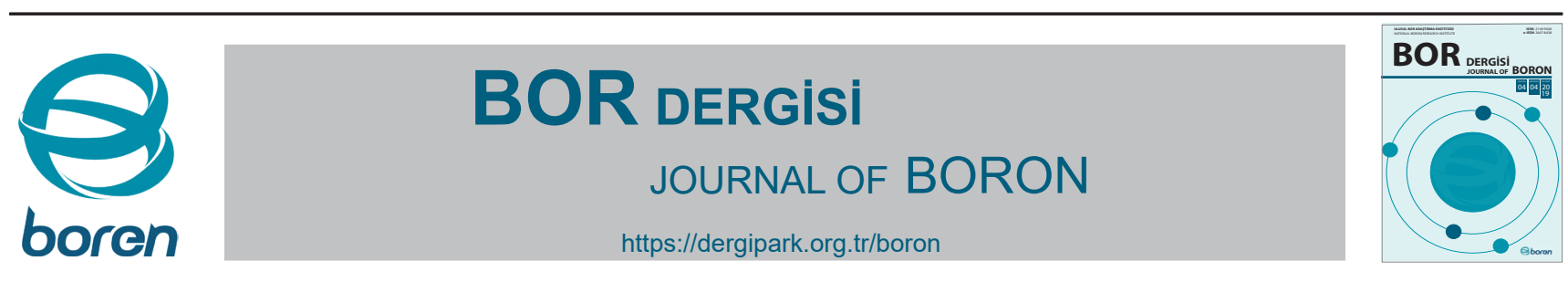

\title{
A new approach for prevention the oxidations and mutations: Zinc borate
}

\author{
Aysel Uğur ${ }^{1}$, Özgür Ceylan², Rukiye Boran ${ }^{3}$, Semih Ayrıkçili ${ }^{4}$, Nurdan Saraç ${ }^{5 *}$, Derviş Yılmaz ${ }^{6}$ \\ ${ }^{1}$ Gazi University, Faculty of Dentistry, Department of Basic Sciences, Section of Medical Microbiology, 06500 Ankara, Turkey, \\ ORCID ID orcd.org/0000-0002-5188-1106 \\ ${ }^{2}$ Mugla Sitki Kocman University, Department of Food Processing, Ula Ali Kocman Vocational School, Turkey, \\ ORCID ID orcd.org/0000-0002-1865-1093
}

${ }^{3}$ Aksaray University, Department of Medical Services and Techniques, Medical Laboratory Program, Vocational School of Health Service, Turkey, ORCID ID orcd.org/0000-0003-2395-2445

${ }^{4}$ Gazi University, Faculty of Dentistry, Department of Oral and Maxillofacial Surgery, 06500 Ankara, Turkey, ORCID ID orcd.org/0000-0002-1606-4151

${ }^{5}$ Mugla Sitki Kocman University, Department of Biology, Faculty of Science, 48000 Mugla, Turkey, ORCID ID orcd.org/0000-0001-7676-542X

${ }^{6}$ Gazi University, Faculty of Dentistry, Department of Oral and Maxillofacial Surgery, 06500 Ankara, Turkey, ORCID ID orcd.org0000-0002-5468-4546

\section{ARTICLE INFO}

Article history:

Received 04 June 2019

Received in revised form 24 December 2019

Accepted 26 December 2019

Available online 31 December 2019

Research Article

DOI: $10.30728 /$ boron. 573718

\section{Keywords:}

Zinc borate,

Antioxidant,

Antimutagenic

Cytotoxic effect.

\begin{abstract}
Zinc borate is a white crystalline powder substance with variable composition $\left(34 \% \mathrm{~B}_{2} \mathrm{O}_{3}, 45 \% \mathrm{ZnO}\right.$ and $\left.20 \% \mathrm{H}_{2} \mathrm{O}\right)$. It is used as a fungus and mildew inhibitor, to fire proof textiles, and for other uses. Although there are limited studies about the biologic properties of this compound. The present study was aimed to investigate the antioxidant and antimutagenic activity of zinc borate and also to figure out its cytotoxic effect. Antioxidant activity of zinc borate was determined with $\beta$ carotene linoleic acid and DPPH radical scavenging assays. The mutagenicity and antimutagenic activity was determined with AMES/ Salmonella microsomal test systems using Salmonella typhimurium TA98 and TA100 strains. The cytotoxic effect of zinc borate was evaluated by 3-(4,5-dimethylthiazol-2-yl)-2,5-diphenyltetrazolium bromide (MTT) assay using mouse fibroblast L929 cell line. When compared to the control, \% inhibition values of $1 \mathrm{mg} / \mathrm{mL}$ zinc borate for DPPH radical scavenging and $\beta$ - carotene linoleic acid tests were calculated as $13.50 \%$ and $30 \%$, respectively. At the tested concentrations, zinc borate did not exhibit any mutagenic effect. Zinc borate exhibited low antimutagenic activity at 0.2 and $0.04 \mathrm{mg} /$ plate concentrations on S. typhimurium TA98 strain while it exhibited no antimutagenic activity on S. typhimurium TA100 strain. In vitro toxicity against L929 cell line with $\mathrm{IC}_{50}$ values of zinc borate were found to be $40.70 \mu \mathrm{g} / \mathrm{mL}$ and $32.93 \mu \mathrm{g} /$ $\mathrm{mL}$ for $24 \mathrm{~h}$ and $72 \mathrm{~h}$, respectively. In spite of the low DPPH free radical scavenging activity, zinc borate has found to have moderate total antioxidant activity besides low antimutagenic potential. Zinc borate has a potential to use for medical purpose with its antioxidative and antimutagenic properties.
\end{abstract}

\section{Introduction}

Zinc is an essential micronutrient for the human body $[1,2]$. It is important for human health and diseases as it plays a significant role in the immune system function, central nervous system, growth and development, bone metabolism and wound healing [3]. $\mathrm{Zn}$ is also a cofactor for many metalloenzymes necessary for cell membrane, cell repair, growth and proliferation. Deficiency in zinc can cause health complications, excessive intake can also lead to negative side effects. Pathological manifestations of zinc deficiency include the impaired immune function, growth retardation, formation of skin lesions and impaired wound healing [4].
Boron is a required element for plants, and recent studies on the biological importance of boron to various hormonal, nutritional, metabolic and physiological processes shown that is also probably necessary for animals and humans [5-8]. Boron plays a crucial role in embryogenesis, psychomotor skills, immune functions, hormone and lipid metabolism [9], vitamin D3 deficiency [10], wound healing [11], and healthy bone/ teeth growth and maintenance [12].

Zinc borate is an inorganic compound in the form of white crystalline powder. Important properties of zinc borate contain comparatively low water solubility and a high dehydration temperature. The second 
feature is that it allows processing on a wide variety of polymer systems [13].

There are some variants of zinc borates, differing by the zinc/boron ratio and the water content. Many of which can find significant industrial use [13]. For example, it is largely used as a polymer additive. It is also used as flame retardant and preservative in plastic, rubbers, cellulose fibres, paper and textiles. As a polymer additive, it is a fire retardant synergist, charpromoting agent, antidrip agent, smoke and last radiation suppressor, and serves as a modifier of electrical and optical properties $[14,15]$.

Today's most significant commercial zinc borate was produced 40 years ago and currently the annual production in the world exceeds 10000 metric tons [13]. Zinc borate as $2 \mathrm{ZnO} .3 \mathrm{~B}_{2} \mathrm{O}_{3} \cdot 3,5 \mathrm{H}_{2} \mathrm{O}$ (hexaboron dizinc undecaoxide) was developed by the field experts at Eti Maden. It can be used all over life because it can be combined with safer, long lasting, durable and economical products in our living space [14].

The living cells are often exposed to potentially damaging free radical species, which origin may be both extra- and intracellular. The cellular targets of reactive oxygen species (ROS) include DNA, lipids and proteins; and they are highly mutagenic/genotoxic and damage cellular macromolecules [16]. Oxidative stress caused by ROS may be the primary cause of various degenerative diseases (e.g., cardiovascular, cancer and neurodegenerative) $[17,18]$. Antioxidants react with ROS to remove radicals and produce less aggressive chemical species [19]. It is also known that antimutagens play a significant role in reducing the damage caused by oxidants [20].

The present study was aimed to determine the antioxidant and antimutagenic activities of zinc borate and also to figure out its cytotoxic effect. Antioxidant activity of zinc borate was determined with DPPH radical scavenging activity and $\beta$ - carotene linoleic acid assays. The mutagenicity and antimutagenic activity was determined with AMES/Salmonella microsomal test systems using Salmonella typhimurium strains (TA98 and TA100). The cytotoxic effect of zinc borate was evaluated by MTT assay using mouse fibroblast L929 cell line.

\section{Materials and methods}

\subsection{Antioxidant activities}

The antioxidant activity of zinc borate (Sigma Aldrich)( $\left.\mathrm{B}_{2} \mathrm{O}_{6} \mathrm{Zn}_{3}, \mathrm{MA}: 313.758 \mathrm{~g} / \mathrm{mol}\right)$ using the $\beta$-carotene/linoleic acid assay was assayed by the method of Rauter et al. [21]. In brief, $1 \mathrm{~mL}$ of b-carotene $(0.5 \mathrm{mg} / \mathrm{mL}$ in chloroform) was mixed with $25 \mu \mathrm{L}$ of linoleic acid and $200 \mathrm{mg}$ of Tween 60. The mixture was shaken and evaporated to remove chloroform. Then, $100 \mathrm{~mL}$ of oxygenated distilled water was added to the mixture and agitated. From this emulsion, $2.5 \mathrm{~mL}$ transferred into different test tubes containing $0.5 \mathrm{~mL}$ of the zinc borate. The initial absorbance of samples was measured after $1 \mathrm{~min}$ of vortexing at $470 \mathrm{~nm}$. Samples were incubated for $60 \mathrm{~min}$ at $50^{\circ} \mathrm{C}$, and the second absorbance was measured at $470 \mathrm{~nm}$ after $1 \mathrm{~min}$ of vortexing. The measurement was carried out at 30 min intervals. Deionised water and ascorbic acid were used as a blank and positive controls, respectively. Antioxidant activity of zinc borate was calculated using the following formulation:

$\ln (\mathrm{Abs})=\ln \left(\mathrm{Abs}_{0}\right)+R \times t$,

where $R$, the bleaching rate

$\mathrm{AA}(\%)=\left[\left(R_{\text {blank }}-R_{\text {sample }}\right) / R_{\text {blank }}\right] \times 100$,

where $R_{\text {blank }}$ and $R_{\text {sample }}$ are the oxidation rates of negative control and sample containing the zinc borate, respectively.

DPPH radical scavenging activity of the zinc borate was detected by the method of Ebrahimabadi et al. [22] with minor modifications [23]. One $\mathrm{mL}$ DPPH (0.2 $\mathrm{mM}$ in $95 \%$ ethanol) was mixed with $1 \mathrm{~mL}$ of the zinc borate $(1 \mathrm{mg} / \mathrm{ml})$ of various concentrations in $95 \%$ ethanol. After vortexing, the tubes were left in the dark for $30 \mathrm{~min}$ at room temperature, after which the absorbance was measured against a blank at $517 \mathrm{~nm}$. Deionised water and ascorbic acid were used as a blank and positive controls, respectively.

DPPH radical scavenging activity was calculated as follows:

Inhibition $(\%)=\left[\left(\mathrm{OD}_{\text {blank }}-\mathrm{OD}_{\text {sample }}\right) / \mathrm{OD}_{\text {blank }}\right] \times 100$

$$
\begin{aligned}
& \mathrm{OD}_{\text {blank }}: \text { Absorbance of the blank } \\
& \mathrm{OD}_{\text {sample }}: \text { Absorbance of the sample }
\end{aligned}
$$

Each experimental group was repeated 3 times.

\subsection{Mutagenicity and antimutagenic activity}

Test bacterial strains were examined primarily for their genetic integrity and spontaneous mutation rates. Then cytotoxic doses of the zinc borate were detected according to Mortelmans and Zeiger [24].

The mutagenicity of zinc borate at the subcytotoxic doses on the test bacteria, was made using the plate/ incorporation method [25]. The positive controls used 4-nitro-o-phenylenediamine (4-NPD) for the $S$. typhimurium TA98 strain and sodium azide $\left(\mathrm{NaN}_{3}\right)$ for the S. typhimurium TA100 strain. The plates were incubated for $48 \mathrm{~h}$ at $37^{\circ} \mathrm{C}$ and $\mathrm{His}^{+}$revertant colonies were counted. 
The antimutagenicity against 4-NPD and $\mathrm{NaN}_{3}$ was assayed by incubating without and with zinc borate at the subcytotoxic doses on the test bacteria (200 and $40 \mu \mathrm{g} /$ plate for TA 98, 500, 100 and $20 \mu \mathrm{g} /$ plate for TA $100)$, using S. typhimurium TA98 or TA100. Ethanol/ water $(1: 1, \mathrm{v} / \mathrm{v})$ was used to determine spontaneous reversion. The plates were incubated for $72 \mathrm{~h}$ at $37^{\circ} \mathrm{C}$ and the $\mathrm{His}^{+}$revertants were counted. For the antimutagenicity assays, the \% inhibition was calculated as follows:

$\%$ inhibition= $[1-(\mathrm{T}-\mathrm{S}) /(\mathrm{M}-\mathrm{S})] \times 100$

$\mathrm{T}$ is the number of revertant colonies in the presence of mutagen and the zinc borate, $\mathrm{M}$ is the number of revertant colonies induced by the mutagen and, $\mathrm{S}$ is the number of spontaneous revertants. To monitor the mutagenicity and antimutagenicity, all doses were studied in three replicates and four parallels.

\subsection{Cytotoxicity}

Cytotoxicity evaluation of the zinc borate on L929 fibroblast cells were screened using MTT colorimetric assay and doneby Anadolu University Plant, Drug and Scientific Research Center. Briefly, cells was cultured in Dulbecco's Modified Eagle's Medium (DMEM)-high glucose, supplemented with 10\% heat-inactivated Fetal Calf Serum (FCS), L-glutamine (2 mM), antibiotic-antimycotic solution (10.000-unit penicillin, $10 \mathrm{mg}$ streptomycin and $25 \mu \mathrm{g}$ amphotericin B per $\mathrm{mL}$ ). Cells were maintained at $37^{\circ} \mathrm{C}$, in a humidified atmosphere of $5 \% \mathrm{CO}_{2}$. After being detached from culture flasks with $0.05 \%$ trypsin solution, cells were passaged to 96-well microtiter tissue culture plates (10.000 cells per well), and incubated at $37^{\circ} \mathrm{C}$, in a humidified atmosphere of $5 \% \mathrm{CO}_{2}$ for $24 \mathrm{~h}$. After then 76.19, 19.05, $4.76,1.19$ and $0.3 \mu \mathrm{g} / \mathrm{mL}$ of zinc borate were added to the wells and incubated for 24 and $72 \mathrm{~h}$ at the same conditions, after which $20 \mu \mathrm{l}$ of MTT $(5 \mathrm{mg} / \mathrm{mL}$, prepared in phosphate-buffered saline) was added to each well and incubated for additional $3 \mathrm{~h}$. The medium containing MTT was then poured off and $100 \mu \mathrm{L}$ of DMSO was used to solubilize the formed formazan crystals in each well. Plates were put in an orbital shaker for 15 minutes at orbital shaker and the absorbance was measured at $540 \mathrm{~nm}$ using microplate reader (Thermo Scientific Multiskan FC, Thermo Fischer, Vantaa, Finland). Each experimental group was repeated 3 times with six replicates.
The $\%$ cell inhibition was determined using the following formula and the graph between \% cell inhibition and concentration were plotted, from which $\mathrm{IC}_{50}$ was calculated:

$$
(\%)=\left[100 \times\left(\text { Sample }_{\text {abs }}\right) /\left(\text { Control }_{\text {abs }}\right)\right]
$$

\section{Results and discussion}

The antioxidative potential of zinc borate at tested concentration are shown at Table 1. Zinc borate exhibit low $\mathrm{DPPH}$ free radical scavenging activity at $1 \mathrm{mg} / \mathrm{mL}$ concentration while at the same concentration it exhibitied moderate total antioxidant activity, respectively.

It is known that ROS play a bi-directional act in biological systems, since they can be beneficial or detrimental to living systems [26]. The detrimental impacts of ROS are offset by the activity of antioxidant enzymes as well as non-enzymatic antioxidants [27]. Although the cell's antioxidant defense system opposes oxidative damage, it has been suggested that oxidative damage accumulates throughout the life cycle and radical damage to DNA, proteins and lipids play a key role in age-dependent diseases development such as arthritis, neurodegenerative disorders, cancer, arteriosclerosis and other conditions [28].

Boron was found to have potential effects against genotoxicity and lipid peroxidation by increasing antioxidant defence mechanism [29] and it reduces oxidative stress caused by malathion and acetylcholinesterase inhibition [30]. Boron was also reported to inhibit the molybdenum containing proteins, proliferating cell nuclear antigen index and improve oxidative stress in hepatocellular carcinoma [31]. Prasad [32] reported that zinc supplementation to elderly individuals reduced the incidence of infections, plasma oxidative stress markers and inflammatory cytokine formation, and reported that plasma zinc levels increased.

According to the mutagenicity assay, zinc borate didn't exhibit any mutagenic efficiency at the tested concentrations, including the $\mathrm{IC}_{50}$ doses on the L929 fibroblast cells, made with S. typhimurium TA98 and TA100 (data not shown).

The effects on 4-NPD and $\mathrm{NaN}_{3}$ mutagens were used to determine the antimutagenic property of zinc borate. The results were estimated using the standard

Table 1.The antioxidant activity results of zinc borate

\begin{tabular}{|c|c|c|c|}
\hline \multirow{2}{*}{ Sample } & \multirow{2}{*}{ Concentration } & \multicolumn{2}{|c|}{$\%$ inhibition } \\
\hline & & $\mathrm{DPPH}^{\mathrm{a}}$ & $\beta$-carotene-linoleic acid \\
\hline Zinc borate & $1 \mathrm{mg}$ & $13.5 \pm 0.034$ & $30 \pm 0.024$ \\
\hline \multirow[t]{2}{*}{ Ascorbic acid } & $10 \mathrm{mg}$ & $83 \pm 0.062$ & $66.4 \pm 0.054$ \\
\hline & $1 \mathrm{mg}$ & $72 \pm 0.076$ & $48 \pm 0.044$ \\
\hline
\end{tabular}


Table 2. The antimutagenicity results of the zinc borate for S. typhimurium TA98 and TA100 strains.

\begin{tabular}{|c|c|c|c|c|c|}
\hline \multirow{3}{*}{ Test items } & \multirow{3}{*}{$\begin{array}{c}\text { Concentration } \\
(\mu \mathrm{g} / \text { plate })\end{array}$} & \multicolumn{4}{|c|}{ Number of revertant colonies } \\
\hline & & \multicolumn{2}{|c|}{ TA98 } & \multicolumn{2}{|c|}{ TA100 } \\
\hline & & $\begin{array}{c}\text { Mean } \pm \\
\text { S.D. }\end{array}$ & Inhibition \% & $\begin{array}{c}\text { Mean } \pm \\
\text { S.D. }\end{array}$ & $\begin{array}{c}\text { Inhibition } \\
\%\end{array}$ \\
\hline Negative control & & $21.66 \pm 3.05^{c}$ & & $199.5 \pm 16.2^{b}$ & \\
\hline $\begin{array}{l}\text { Positive control } \\
4-\mathrm{NPD}^{\mathrm{a}} \\
\mathrm{NaN}_{3}{ }^{\mathrm{b}}\end{array}$ & $\begin{array}{l}3.0 \\
8.0\end{array}$ & $636 \pm 49.75$ & & $1686.66 \pm 172.4$ & \\
\hline Zinc borate & $\begin{array}{c}500 \\
200 \\
100 \\
40 \\
20\end{array}$ & $\begin{array}{c}\text { NT } \\
505.66 \pm 46.5 \\
\text { NT } \\
499.5 \pm 72.8 \\
\text { NT }\end{array}$ & $\begin{array}{l}20.49 \\
21.46\end{array}$ & $\begin{array}{c}1444 \pm 108.29 \\
\text { NT } \\
1470 \pm 155.56 \\
\text { NT } \\
1513.33 \pm 90.18\end{array}$ & $\begin{array}{r}14.38 \\
12.84 \\
10.27\end{array}$ \\
\hline
\end{tabular}

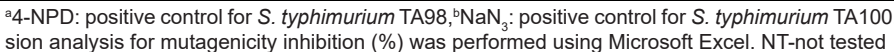

plate incorporation method and summarized in Table 2. The zinc borate showed low antimutagenic effects against 4-NPD at 0.2 and $0.04 \mathrm{mg} /$ plate concentrations. Whereas, zinc borate didnt have any antimutagenic efficiency against $\mathrm{NaN}_{3}$, as all values were below the limit of $20 \%$.

Considering that mutations are an early stage of carcinogenesis, short-term tests such as Salmonellal reversion testing can be said to be very important in the early identification of mutagens/carcinogens as well as antimutagens/anticarcinogens [33]. Therefore, prior identification of substances that can induce mutations has happen an considerable process in safety evaluation. Chemicals that can cause/induce mutations can potentially harm the reproductive tract that leads to mutations and reproductive problems in future generations. Mutagenic chemicals can also induce cancer, and this concern has led most of the mutagenic testing programs [24]. The Salmonella mutagenicity test is conceived to define chemically induced mutagenesis [34].
In this study, Ames Salmonella/microsome mutagenicity test was used to define the mutagenic and antimutagenic potential of zinc borate. The current research focuses on the development of efforts to diminish the risk of cancer through the use of chemoprophylactic and chemopreventive compounds, as cancer prevalence rates rise in the worldwide [35].

In addition, the effect of zinc borate on cell viability of L929 fibroblast cells are given at Figure 1. According to the MTT analysis results applied at $24 \mathrm{~h}$ and $72 \mathrm{~h}$, the $I_{50}$ values of zinc borate were found to be 40.70 $\mu \mathrm{g} / \mathrm{mL}$ and $32.93 \mu \mathrm{g} / \mathrm{mL}$, respectively (Table 3). According to the data obtained from MTT test, there was no significant difference between zinc borate treated groups and non-zinc borate treated groups $(p<0.05)$.

It is known that boron is significant for animal cell development and replication, but the basic mechanism remains unclear [36]. Studies in the literature show that boron compounds have no mutagenic or carcinogenic activity on cell and living organisms. These

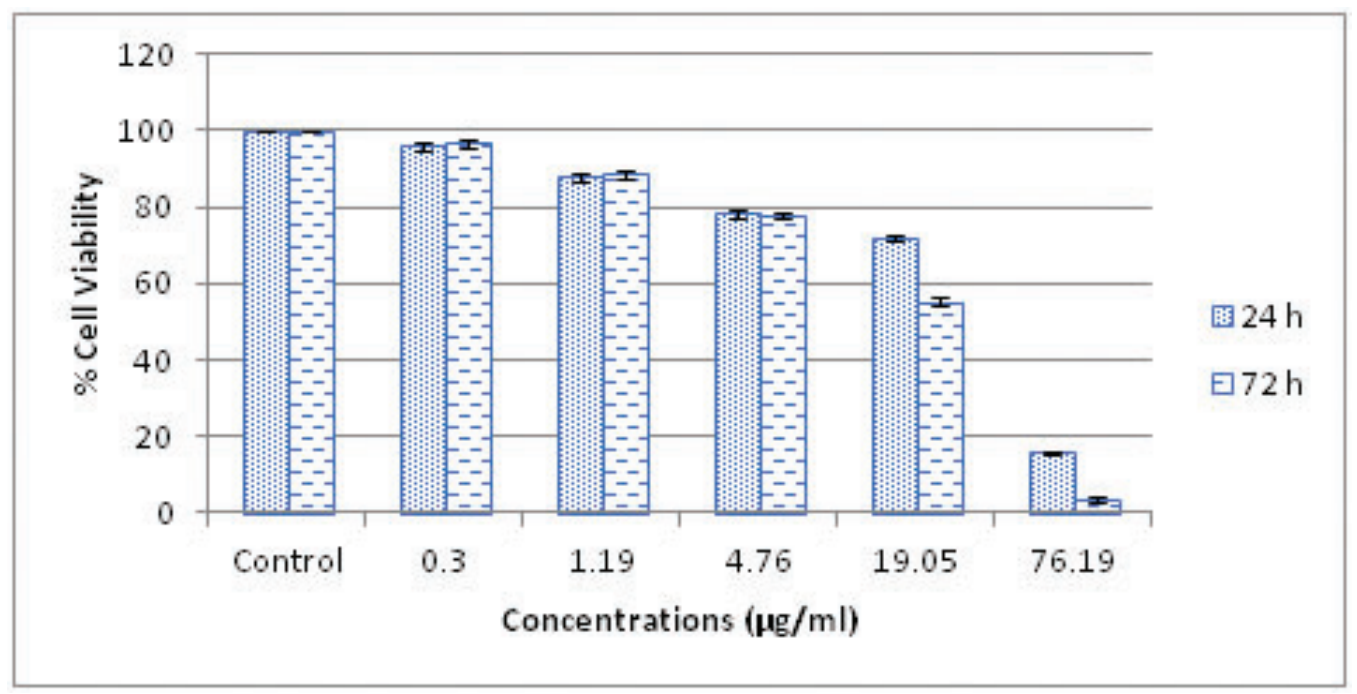

Figure 1. The effect of zinc borate on cell viability of L929 fibroblast cells $(n=6)$. 
Table 3. The $I C_{50}$ values of zinc borate on L929 fibroblast cells $(n=6)$.

\begin{tabular}{ccccc}
\hline Material & $\mathbf{2 4} \mathbf{h}$ & $\mathbf{R}^{\mathbf{2}}$ & $\mathbf{7 2} \mathbf{h}$ & $\mathbf{R}^{\mathbf{2}}$ \\
\hline $\begin{array}{c}\text { Zinc borate } \\
(\mu \mathrm{g} / \mathrm{ml})\end{array}$ & 40.70 & & 32.93 & \\
$\begin{array}{c}\text { Zinc borate } \\
(\mu \mathrm{M})\end{array}$ & 129.7 & 0.98 & 104.9 & 0.96 \\
\hline
\end{tabular}

studies have been conducted with well-known boron compounds such as borax, boric acid or sodium tetraborate [37]. Studies have shown that boric acid is not genotoxic in human blood cultures and supports antioxidant enzyme activities [38]. In a study done by the same researchers, the hepatoprotective effects of boric acid were investigated [39]. As the effects on malignancies have recently emerged, attention to boron compounds is increasing.

It is possible to find studies done using different boron compounds and different cell groups in the literature. In a study, sodium tetraborate and boric acid at 1.000 $\mu \mathrm{M}$ concentration applied to healthy human lymphocytes by MTT methods caused a $25 \%$ and $20 \%$ reduction in mitochondrial activity, respectively. It was found that the same concentration of sodium tetraborate and boric acid resulted in a $20 \%$ and $50 \%$ reduction in mitochondrial activity of human leukemia cells, respectively. Especially, the cell viability of human leukemia cells was significantly decreased at a concentration of $100 \mu \mathrm{M}$ for an incubation period of $48 \mathrm{~h}$ [40]. Similarly, in our study, the cell viability of L929 fibroblast cells was $50 \%$ reduced at $129.7 \mu \mathrm{M}$ concentrations after $24 \mathrm{~h}$ incubation.

In another study the $400 \mathrm{mg} / \mathrm{L}$ concentrations of some synthesized borenium compounds were non-cytotoxic on cultured human blood cells [41]. Similarly, in a study reveals that both synthesized hexagonal boron nitrides and boric acid are not cytotoxic at lower than $22 \mu \mathrm{g} / \mathrm{mL}$ boron containing concentrations on brain neuronal mHippo E-14 cells [42]. Administration of $<0.5 \mathrm{mmol} / \mathrm{L}$ boron significantly promoted the viability of Sertoli cells $(P<0.01)$; however, the exposure to high dose (>10 $\mathrm{mmol} / \mathrm{L}$ ) of boron exhibited significant adverse effects [43]. Deshayes et al. [44] observed cytotoxic effects on B16F10 murine melanoma cells of phenyl boronic acid nanoparticles $\left(\mathrm{IC}_{50}: 186 \mu \mathrm{M}\right)$. In our study, the $\mathrm{IC}_{50}$ values of zinc borate on L929 fibroblast was determined as $129.7 \mu \mathrm{M}$ after $24 \mathrm{~h}$ incubation and $104.9 \mu \mathrm{M}$ after $72 \mathrm{~h}$. The $\mathrm{IC}_{50}$ values of zinc borate is lower than the boronic acid nanoparticles which given above study. However, there is no article that considers the evaluation of zinc borate on fibroblast cells.

\section{Conclusions}

The study was performed to evaluate the antioxidant and antimutagenic activity, and the mutagenic and cytotoxic potential of zinc borate. Zinc borate found to have moderate total antioxidant activity. At the tested concentrations, zinc borate didn't exhibit any mutagenic effect, including the $\mathrm{IC}_{50}$ values on L929 fibroblast cell lines. Zinc borate exhibited low antimutagenic effect on S. typhimurium TA98 strain which was induced with 4-NPD whereas not founded on TA100 strain. In vitro toxicity against $\mathrm{L} 929$ cell line with $\mathrm{IC}_{50}$ values of zinc borate were found to be $40.70 \mu \mathrm{g} / \mathrm{mL}$ and 32.93 $\mu \mathrm{g} / \mathrm{mL}$ for $24 \mathrm{~h}$ and $72 \mathrm{~h}$, respectively. As a result of this study, zinc borate which was found to have no genotoxic effect and cytotoxicity at the tested concentrations, it has a potential for medical applications with its antioxidative and antimutagenic properties.

\section{Acknowledgements}

This study is a part of PhD thesis of Semih Ayrıkcıl.

\section{References}

[1] Zago L.B., Danguise E., González C.I., Río M.E., Callegari M., Vitamin A and zinc levels in gastroenterological surgical patients: Relation with inflammation and postoperative complications, Nutr. Hosp., 26 (6), 14621468, 2011.

[2] Atasoy H.B., Ulusoy Z.I.A., The relationship between zinc deficiency and children's oral health, Pediatr. Dent., 34, 383-386, 2012.

[3] Roohani N., Hurrell R., Kelishadi R., Schulin R., Zinc and its importance for human health: An integrative review, Journal of Research in Medical Science, 18, 144-157, 2013.

[4] Lin P.H., Sermersheim M., Li H., Lee P., Steinberg S., Ma J., Zinc in wound healing modulation, Nutrients, 10 (1), 16, 2018.

[5] World Health Organization, Trace Elements in Human Nutrition and Health. 0-361, 1996.

[6] Basoglu A., Sevinc M., Birdane M., Boydak M., Efficacy of borax in the prevention of fatty liver in dairy cows, J. Vet. Intern. Med., 16, 732-735, 2002.

[7] Kabu M., Akosman M.S., Biological Effects of Boron, Rev. Environ. Contam. Toxicol., 225, 57-75, 2013.

[8] Uluisik I., Karakaya H.C., Koc A., The importance of boron in biological systems, J. Trace Elem. Med. Biol., 45, 156-162, 2018.

[9] Basoglu A., Baspinar N., Ozturk A.S., Akalin P.P., Effects of long-term boron administration on high-energy diet-induced obesity in rabbits: NMR-based metabonomic evaluation, J. Anim. Vet. Adv., 10 (12), 15121515, 2011.

[10] Hunt C.D., The Biochemical effects of physiologic 
amounts of dietary boron in animal nutrition models, Environ. Health Perspect., 102 (7), 35-42, 1994.

[11] Demirci S., Doğan A., Aydın S., Dülger E. Ç., Şahin F., Boron promotes streptozotocin-induced diabetic wound healing: Roles in cell proliferation and migration, growth factor expression, and inflammation, Mol. Cell. Biochem., 417 (1-2), 119-33, 2016.

[12] Nielsen F. H. Meacham S., Growing Evidence for Human Health Benefits of Boron, J. Evid. Based Complementary Altern. Med., 16 (3), 169-180, 2011.

[13] Schubert D. M., Alam F., Visi M. Z., Knobler C. B., Structural characterization and chemistry of the industrially important zinc borate, $\mathrm{Zn}\left[\mathrm{B}_{3} \mathrm{O}_{4}(\mathrm{OH})_{3}\right]$, Chem. Mater., 15 (4), 866-871, 2003.

[14] Anonymous, 2019a, http://www.etimaden.gov.tr/en/ zinc-borate (15.03.2019).

[15] Anonymous, 2019b, http://pmep.cce.cornell.edu/profiles/fung-nemat/tcmtb-ziram/zinc-borate/fung-profzinc-borate.html (15.03.2019).

[16] Sghaier M.B., Ismail M.B., Bouhlel I., Ghedira K., Chekir-Ghedir L., Leaf extracts from Teucrium ramosissimum protect against DNA damage in human lymphoblast cell K562 and enhance antioxidant, antigenotoxic. and antiproliferative activity, Environ. Toxicol. Pharmacol., 44, 44-52, 2016.

[17] Schieber M., Chandel N. S., ROS function in redox signalling and oxidative stress, Current Biology, 24, 453462, 2014.

[18] El-Kenawi A., Ruffell B., Inflammation, ROS, and mutagenesis, Cancer Cell, 32, 727-729, 2017.

[19] Viswanatha G.L.S., Vaidya S.K., Ramesh C., Krishnadas N., Rangappa S., Antioxidant and antimutagenic activities of bark extract of Terminalia arjuna, Asian Pacific Journal of Tropical Medicine, 965-970, 2010.

[20] Frassinetti S., Croce C.M.D., Caltavuturo L., Longo V., Antimutagenic and antioxidant activity of Lisosan G in Saccharomyces cerevisiae, Food Chem., 135 (3), 2029-2034, 2012.

[21] Rauter A. P., Dias C., Martins A., Branco I., Neng N.R., Nogueira J. M., Goulart M., Silva F. V. M., Justino J., Trevitt C., Waltho J. P., Non-toxic Salvia sclareoides Brot. extracts as a source of functional food ingredients: Phenolic profile, antioxidant activity and prion binding properties, Food Chem., 132 (4), 1930-1935, 2012.

[22] Ebrahimabadi A. H., Mazoochi A., Kashi F. J., DjafariBidgoli Z., Batooli H., Essential oil composition and antioxidant and antimicrobial properties of the aerial parts of Salvia eremophila Boiss. from Iran, Food Chem. Toxicol., 48 (5), 1371-1376, 2010.

[23] Boran, R., Ugur, A., The mutagenic, antimutagenic and antioxidant properties of Hypericum lydium, Pharm. Biol., 55 (1), 402-405, 2017.

[24] Mortelmans K., Zeiger E., The Ames Salmonella/microsome mutagenicity assay, Mutat. Res. Fundam. Mol. Mech. Mutagen., 455 (1-2), 29-60, 2000.

[25] Maron D.M., Ames, B.N., Revised methods for the Salmonella mutagenicity test, Mutat. Res. Environ. Mutagen. Relat. Subj., 113 (3-4), 173-215, 1983.
[26] Valko M., Izakovic M., Mazur M., Rhodes C. J., Telser $\mathrm{J} .$, Role of oxygen radicals in DNA damage and cancer incidence, Mol. Cell. Biochem., 266 (1-2), 37-56, 2004.

[27] Halliwell B., Commentary oxidative stress, nutrition and health, Experimental strategies for optimization of nutritional antioxidant intake in humans, Free Radical Res., 25 (1), 57-74, 1996.

[28] Halliwell B., Gutteridge J.M., Free radicals in biology and medicine. Oxford University Press, USA, 2015.

[29] Ince S., Kucukkurt I., Demirel H. H., Acaroz D. A., Akbel E., Cigerci I. H., Protective effects of boron on cyclophosphamide induced lipid peroxidation and genotoxicity in rats, Chemosphere, 108, 197-204, 2014.

[30] Coban F. K., Ince S., Kucukkurt I., Demirel H. H., Hazman O., Boron attenuates malathion-induced oxidative stress and acetylcholinesterase inhibition in rats, Drug Chem. Toxicol., 38 (4), 391-399, 2015.

[31] Zafar H., Ali S., Boron inhibits the proliferating cell nuclear antigen index, molybdenum containing proteins and ameliorates oxidative stress in hepatocellular carcinoma, Arch. Biochem. Biophys., 529 (2), 66-74, 2013.

[32] Prasad A. S., Zinc is an antioxidant and anti-inflammatory agent: its role in human health, Front. Nutr., 1, 14, 2014.

[33] Horn R. C., Vargas V. M. F., Antimutagenic activity of extracts of natural substances in the Salmonella/microsome assay, Mutagenesis, 18 (2), 113-118, 2003.

[34] Ames B.N., McCann J., Yamasaki E., Methods for detecting carcinogens and mutagens with the Salmonella/ mammalian- microsome mutagenicity test, Mutation Research/ Environmental Mutat. Res. Environ. Mutagen. Relat. Subj., 31 (6), 347-363, 1975.

[35] Ghazali A.R., Abdullah R., Ramli N., Rajab N.F., Ahmad-Kamal M.S., Yahya N.A., Mutagenic and antimutagenic activities of Mitragyna speciosa Korth extract using Ames test, J. Med. Plants Res., 5 (8), 13451348, 2011.

[36] Eckhert C. D., Boron stimulates embryonic trout growth, J. Nutr., 128 (12), 2488-2493, 1998.

[37] European Centre for Ecotoxicology and Toxicology of Chemicals (ECETOC)., Reproductive and general toxicology of some inorganic borates and risks assessment for human beings, Technical Report, No. 63. Brussels (Belgium): ECETOC; 1995.

[38] Türkez H., Geyikoğlu F., Tatar A., Keleş S., Özkan A., Effects of some boron compounds on peripheral human blood, Zeitschrift für Naturforschung C, 62 (1112), 889-896, 2007.

[39] Türkez H., Geyikoğlu F., Colak S., The protective effect of boric acid on aluminum-induced hepatotoxicity and genotoxicity in rats, Turk. J. Biol., 35 (3), 293-301, 2011.

[40] Cantürk Z., Tunali Y., Korkmaz S., Gulbaş Z., Cytotoxic and apoptotic effects of boron compounds on leukemia cell line, Cytotechnology, 68 (1), 87-93, 2016. 
[41] Oguzkan S. B., Turkez H., Karagul B., Cakir U., Ugras H.I., In vitro cytotoxic and genotoxic effects of newly synthesised boron ionic liquids, Biotechnol. Biotechnol. Equip., 33 (1), 86-92, 2019.

[42] Taşkın I., Şen Ö., Emanet M., Culha M., Yılmaz B., Biocompatibility evaluation of hexagonal boron nitrides on healthy mouse hippocampal cell line and their positive effect on stressed cells, Beilstein Archives, 2019.

[43] Lu L., Zhang Q., Ren M., Jin E., Hu Q., Zhao C., Ef- fects of Boron on Cytotoxicity, Apoptosis, and Cell Cycle of Cultured Rat Sertoli Cells In vitro, Biol. Trace Elem. Res., 1-8, 2019.

[44] Deshayes S., Cabral H., Ishii T., Miura Y., Kobayashi S., Yamashita T., Matsumoto A., Miyahara Y., Nishiyama N., Kataoka K., Phenylboronic acid-installed polymeric micelles for targeting sialylated epitopes in solid tumors, J. Am. Chem. Soc., 135 (41), 15501-15507, 2013. 